\title{
Recent advances on happiness
}

\author{
Maryam Mehri ${ }^{{ }^{*}}$, Fatemeh Rezaei ${ }^{\mathrm{b}}$ and Mohammad Reza Abedi ${ }^{\mathrm{c}}$
}

${ }^{a}$ MS Student, Counseling Department, Islamic Azad University of Khomeinishahr, Khomeinishahr Branch, Daneshjou Blvd, Iran

${ }^{b}$ Assistant Professor, Counseling Department, Islamic Azad University of Khomeinishahr,Khomeinishahr Branch, Daneshjou Blvd, Iran ${ }^{c}$ Associate Professor, Department of Counseling, University of Isfahan, Isfahan, Iran

\section{H R O N I C L E}

Article history:

Received January 12, 2013

Received in revised format

10 April 2013

Accepted 18 April 2013

Available online

April 202013

Keywords:

Mental health

Happiness

\section{A B S T R A C T}

\begin{abstract}
Happiness plays essential role on building prosperity and success in any society. Happiness is one of the essential factors to reach prosperity and success in people's life and jobs but happiness is not always the same as capability, but they may be correlated while capability is a necessary for having a happy life and happiness feeds back on capability in different ways. People who feel happy could better contribute to society and help other people build better future. This study performs a review on recently completed studies on factors, which influence happiness, new definitions of happiness. The study concentrates more on empirical investigations on the concept of happiness.
\end{abstract}

(c) 2013 Growing Science Ltd. All rights reserved.

\section{Introduction}

Happiness is one of the essential factors to reach prosperity and success in people's life and carriers but happiness is not always the same as capability. In fact, they may be correlated while capability is a necessary for having a happy life and happiness feeds back on capability in different ways. Capabilities influence happiness not only at the individual level, but also at the societal level, indirectly. For example, school education may not appear to make pupils any happier, but higher educational degrees are necessary for modern society, which may add to happiness. Therefore, it is necessary to find the interrelations between capability and happiness in making appropriate policy choices.

\section{Recent review}

If the primary objective is greater happiness, we need to know about the kind of capabilities for happiness in the given circumstances. If the cultivation of capabilities is also ranked, one must at least learn the possible loss of happiness (Veenhoven, 2010).

Corresponding author. Tel: +989132022795

E-mail: maryam.mehri@iaukhsh.ac.ir (M. Mehri)

(C) 2013 Growing Science Ltd. All rights reserved. doi: 10.5267/j.msl.2013.04.018 
Brebner et al. (1995) studied relationships between measures of happiness and personality, using multiple regressions and a range of personality measures and reported that extraversion and neuroticism were the main predictors. Vaillant (2012) investigated seven models for conceptualizing positive mental health including mental health as above normal, epitomized by a DSM-IV's Global Assessment of Functioning (GAF) score of over 80. He also considered mental health as the presence of multiple human strengths rather than the absence of weaknesses; mental health conceptualized as maturity; mental health as the dominance of positive emotions; mental health as high socio-emotional intelligence; mental health as subjective well-being; mental health as resilience.

Bakhtiyar Nasrabadi et al. (2009) investigated the happiness level among the faculty members in Isfahan University of Medical Sciences in Iran. They gathered the necessary data associated with happiness, internal and external happiness factors. They reported no meaningful difference between the mean of happiness scores and internal and external happiness factors. Rojas (2007) explained that heterogeneity in the conceptual referent also could extend to the relationship between happiness and income. In fact, income could be an important explanatory variable for some people, while for others it is completely irrelevant. The existence of heterogeneity in the conceptual referent for happiness and, consequently, in the explanatory structure of happiness has important implications for behavioral economics. Happiness pursuing people are anticipated to behave differently if they have various notions of what a happy life is.

Bimonte and Faralla (2012) investigated whether the attitudes and behaviors of alternative tourists, in case study of park visitors, differ with respect to other more mass kinds of tourists, in their case beach tourists. Then, they also looked for understanding whether any relationship existed between selfreported happiness and the kind of tourist one belongs to. Alimoradi et al. (2011) compared the activity of brain/behavioral systems and happiness in male and female students. In this survey, they asked some participants to complete the Gray-Wilson personality Questionnaire (GWPQ) and oxford happiness inventory (0HI). They explained there was a significant difference between two groups in level activity of behavioral activity system (BAS), behavioral inhibition system (BIS) and fight- flight system (FFS). They believed happiness rate and activity level of BAS in males group were more than females group, but females group were more active in BIS and FFS. They also explained that happiness rate was increased by more active BAS.

Ho (2011) performed a survey on happiness and suggested that the positive or negative feelings associated with any activity may be influenced by past events and expectations about the future and may not be intrinsic to the activity. Happiness is different in various people's life cycles. Easterlin (2006), for instance, explained that in the United States happiness rises slightly, on average, from ages 18 to midlife, and declines slowly thereafter. Lubian and Zarri (2011) presented empirical evidence that "tax morale" - taxpayers' intrinsic motivation to pay taxes - constituted a new determinant of happiness, even after controlling for several demographic and socioeconomic factors. They evaluated the strength of tax morale by relying on single items as well as composite multi-item indices based on some data on Italian households for 2004. They reported that fiscal honesty generated a higher hedonic payoff than cheating was in line with neuroeconomic finding. They also gave some insight on the well-known "puzzle of compliance", which is the fact that many individuals pay taxes even when expected penalty and audit probability are extremely low.

Blanchflower and Oswald (2008) provided a new ranking of European nations' GHQ-N6 mental health scores. Peiró (2006) examined the relationships between socio-economic conditions and happiness or satisfaction of individuals in 15 countries. They reported that age, health and marital status were strongly associated with happiness and satisfaction. One the contrary to other studies, unemployment did not seem to be associated with happiness, although it was clearly associated with satisfaction. Income was also strongly associated with satisfaction, but its association with happiness was weaker. Their results pointed to happiness and satisfaction as two distinct spheres of well-being. 
One of the primary concerns on educational systems is to learn about the effect of various factors on improving academic performance and there are literally different studies associated with this issue (Hogan, 1976; Diener, 2006). Andrews and Wilding (2004), for instance, investigated the effects of depression and anxiety to life-stress and achievement in students.

Acar (2011), for instance, investigated social capital's impacts on academic success in education by studying the definition of social capital. According to Diener and Diener (1996) some people were looking for finding happy people but just examined the level of happiness. In fact, most people report a positive level of subjective well-being (SWB), and believe that they were satisfied with domains such as marriage, work, and leisure. According to Agid et al. (2012), happiness is a core dimension of a person's life, associated with both functioning and success. They examined happiness in schizophrenia in relation to both clinical and functional measures of outcome. They concluded that despite marked functional impairment, individuals with first-episode schizophrenia were as happy as controls. McBride (2010) presented some results from the first experimental study of how multiple factors-past payments, social comparisons, and expectations-could affect aspiration formation and reported satisfaction. The study disclosed that expectations and social comparisons significantly influenced reported satisfaction.

Tomer (2011) contributed to an understanding of enduring happiness, which integrates these various approaches. He modified the happiness formula and interpreted it somewhat differently than psychologists and described as $H=S+U_{\mathrm{C}}+E$. In this equation $H$ is an individual's enduring happiness; $S$ is an individual's set point, one's inherited disposition to happiness; $U_{\mathrm{C}}$ is the contribution to happiness made by the relatively utilitarian or hedonic aspects of an individual's circumstances; and $E$ is the contribution to happiness made by the eudaimonic aspect of life. According to Buddhism, ordinary people typically suffer from a number of imbalances, and thus experience some degree of unhappiness. An important implication of the new technique was that people could improve their $H$ through endeavor to remedy their imbalances, thereby raising the eudaimonic component of their $H$. The $U_{\mathrm{C}}$ and $E$ variables described how much the individual invested in tangible assets and intangible capital, which contributed to his/her happiness.

Lyubomirsky (2001) in another study studied why some people were happier than others and investigated the role of cognitive and motivational processes in well-being. Gil-Olarte Márquez et al. (2006) investigated the effect of emotional intelligence on social competence and academic achievement in high school students. Veenhoven and Choi (2012) studied whether intelligence could boost happiness and Smartness of all pays more than being smarter than others do. Deary et al. (2007) performed a 5-year prospective longitudinal investigation on 70,000 + English children and examined the association between psychometric intelligence at age 11 years and educational achievement in national examinations in 25 academic subjects at age 16. The correlation between a latent intelligence trait and a latent trait of educational achievement was reported as 0.81 and general intelligence contributed to success on all 25 subjects.

\section{Conclusion}

As we can see from this survey, happiness has different meanings in various places and societies. People in United States have enjoyed happiness when they were young but people in other places may find happiness as they older. Therefore, it is necessary to keep in mind that we cannot make general conclusion on the factors, which influence happiness. For instance, wealth could generate happiness in some societies but it does not necessarily bring prosperity and success on any one's life.

\section{References}

Acar, E. (2011). Effects of social capital on academic success: A narrative synthesis. Educational Resource Review, 6, 456-461. 
Agid, O., McDonald, K., Siu, C., Tsoutsoulas, C., Wass, C., Zipursky, R.B., Foussias, G., \& Remington, G. (2012). Happiness in first-episode schizophrenia. Schizophrenia Research, 141(1), 98-103.

Alimoradi, L., Aubi, S., \& Yousefi, S. (2011). Comparing the activity of brain/behavioral systems and happiness in male and female students. Procedia - Social and Behavioral Sciences, 30, 1576-1580.

Andrews, B., \& Wilding, J. M. (2004). The relation of depression and anxiety to life-stress and achievement in students. British Journal of Psychology, 95(4), 509-521.

Bakhtiyar Nasrabadi, H., Bahrami, S., Keyvanara, M., \& Kalantari, M. (2009). Astudy of the happiness level among the staff of the faculties in Isfahan University of Medical Sciences in 2009. Iran Occupational Health, 6(3), 8-14.

Bimonte, S., \& Faralla, V. (2012). Tourist types and happiness a comparative study in Maremma, Italy. Annals of Tourism Research, 39(4), 1929-1950.

Blackwell, T., \& Case, J. (2008). Strong interest inventory. Rehabilitation Counseling Bulletin, 51 (2), 122-126.

Blanchflower, D.G., \& Oswald, A.J. (2008). Hypertension and happiness across nations. Journal of Health Economics, 27(2), 218-233.

Brebner, J., Donaldson, J., Kirby, N., \& Ward, L. (1995). Relationships between happiness and personality. Personality and Individual Differences, 19(2), 251-258.

Deary, I. J., Strand, S., Smith, P., \& Fernandes, C. (2007). Intelligence and educational achievement. Intelligence, 35(1), 13-21.

Diener, E., \& Diener, C. (1996). Most people are happy. Psychological science,7(3), 181-185.

Diener, E. (2006). Guidelines for national indicators of subjective well-being and ill-being. Applied Research in Quality of Life, 1(2), 151-157.

Donnay, D. (1997). E.K. Strong's legacy and beyond: 70 years of the strong interest inventory. Career Development Quarterly, 46 (1), 2-22.

Easterlin, R.A. (2006). Life cycle happiness and its sources: Intersections of psychology, economics, and demography. Journal of Economic Psychology, 27(4), 463-482.

Gil-Olarte Márquez, P., Palomera Martín, R., \& Brackett, M. A. (2006). Relating emotional intelligence to social competence and academic achievement in high school students. Psicothema, 18, 118-123.

Lubian, D., \& Zarri, L. (2011). Happiness and tax morale: An empirical analysis. Journal of Economic Behavior \& Organization, 80(1), 223-243.

Lyubomirsky, S. (2001). Why are some people happier than others? The role of cognitive and motivational processes in well-being. American Psychologist,56(3), 239.

McBride, M. (2010). Money, happiness, and aspirations: An experimental study. Journal of Economic Behavior \& Organization, 74(3), 262-276.

Ho, L.S. (2011). Hong Kong's happiness indices: What they tell us about LIFE? The Journal of Socio-Economics, 40(5), 564-572.

Hogan, R. (1976). Personality theory perso logical tradition. Prentice - hall. Englewood cliffs, New Jersey.

Peiró, A. (2006). Happiness, satisfaction and socio-economic conditions: Some international evidence. The Journal of Socio-Economics, 35(2), 348-365.

Rojas, M. (2007). Heterogeneity in the relationship between income and happiness: A conceptualreferent-theory explanation. Journal of Economic Psychology, 28(1), 1-14.

Tomer, J.F. (2011). Enduring happiness: Integrating the hedonic and eudaimonic approaches. The Journal of Socio-Economics, 40(5), 530-537.

Veenhoven, R. (2010). Capability and happiness: Conceptual difference and reality links. The Journal of Socio-Economics, 39(3), 344-350.

Veenhoven, R., \& Choi, Y. (2012). Does intelligence boost happiness? Smartness of all pays more than being smarter than others. International Journal of Happiness and Development, 1(1), 5-27.

Vaillant, G.E. (2012). Positive mental health: is there a cross-cultural definition? World Psychiatry, 11(2), 93-99. 